\title{
Between Sinology and Socialism: Collective Memory of Czech Sinologists in the 1950s
}

\author{
Ter-H sing C heng (T aiwan)
}

\begin{abstract}
7 his paper intends to explore the collective memory of Czech sinologists in the 1950s based on the political zone between sinology and socialism. Czech sinological development in the 1950s was grounded on the personal factor of Prusek and the socialist transformation of new China. Socialist China offers two possibilities for the development of sinology, the first for friendly relations among socialist countries, including overseas students, and the second for studies of contemporary Chinese literature. The developmental framework of Czech sinology in the 1950s, or the social framework of collective memory for the Czech sinologists should be understood in the region under the mutual penetration of sinology and socialist China. This paper, firstly, discusses the background framework of constructing the Czech sinologists in the 1950s the link between new China and the other socialist countries, and the relation between Prusek and socialist China. Secondly, this paper will analyze Czech sinological experiences in the 1950s through Halbwachs' theory of collective
\end{abstract} memory.

Keywords: Czech sinology, socialism, people of sinology, Jaroslav Prusek

\section{Introduction}

Since the 1950s the development of Czech sinology was first of all made possible because "socialism" built a bridge between China and the Czechoslovakia, and secondly, via Czech sinologist Jaroslav Prusek's active promotion. As for the Czech senior sinologists, new China in the 1950s and Prusek belong to their common memory when studying sinology. This paper explores how Czech senior sinologists have constructed their 1950s' memory through Maurice Halbwachs' theoretical discussion on "collective memory". As far as Halbwachs' memory theory is concerned, construction of a collective memory must have a "social framework". This social framework reconstructs the past through the 
present perspective, making memory a construction, not a recovery. As for the 1950s' generation of Czech sinologists, the background framework of getting sinological knowledge is through inspiration from Prusek and the feasibility of contacting socialist China. After the 1970s and 80s, however, "normalization" and "democratization" decided how Czech senior sinologists reconstructed their "social framework" and the link between Sinology and Socialism.

This paper intends to provide an image of how the collective memory of the Czech Prague School of Sinology in the 1950s was constructed. It does so mainly through autobiographical memory, rather than historical memory. Czech sinological development in the 1950s was based on the personal factor of Prusek and the socialist transformation of new China. Socialist China offered two possibilities for the development of sinology, the first for friendly relations among socialist countries, including overseas students, and the second for studies of contemporary Chinese literature. New China's socialist transformation was the best external condition for Prusek, who had met before the contemporary Chinese literature writers in the 1930-1940s, and that made him and his followers focused on contemporary Chinese literature in 1950s' Chinese studies in Czechoslovakia. The developmental framework of Czech sinology in the 1950s, or the social framework of the collective memory of the Czech sinologists should be understood in the region under the mutual penetration of sinology and socialist China. This paper, firstly, discusses how the background framework of Czech sinologist in the 1950s has been constructed - the link between new China and the other socialist countries, and the relation between Prusek and socialist China. Secondly, this paper will analyze the Czech sinological experience in the 1950s through Halbwachs' theory of collective memory.

\section{Jaroslav Prusek and the Framework of Socialism}

The first time the founder of the Prague school of sinology, Jaroslav Prusek (1906-1980), went to China was in 1932 and his main purpose was for academic study. Even though he planned to study Chinese economic history, but after his actual exposure to Chinese society, his research interests shifted to social life, customs and folk arts of the Chinese people. Prusek stayed in China until 1937. During his stay, the Japanese Government invited him to visit Japan, but Prusek remained relatively sympathetic to China, and condemned Japan's aggression atrocities. Prusek traveled everywhere in China. He met Mao Dun and Bing Xin, Ding Ling, Guo Moruo, Shen Congwen, Zheng zhenduo and others, and conversed in letters with Lu Xun. In 1937, after his returning to the Czechoslovakia, he translated the fiction Scream, and published it in the same year. Prusek wrote My Sister-China during his stay in China, which was based on his impressions of 
study and research, and published in 1940. This book "evokes a number of Czech young people's interest in China and the profound love of Chinese culture, so as to encourage their dedication to Chinese studies."

In September 1956 reporters of the Chinese People's Daily led by Li Yanning came to the Oriental Institute in Prague for an interview with Prusek, they published the interview content in People's Daily of October 4, 1956, and praised Prusek for his rich writing works. Among those relating to sinology for example include "On Chinese literature and culture", "Chinese people literature", "Chinese Literature and Education", "New Chinese literature", "President Mao Ze-Dong and Chinese Literature", and "Literature and People Traditional After Liberation ". In addition, Prusek "celebrated the Chinese revolution with great enthusiasm, and introduced the new China. From 1932, he used the name 'Batac' to write many newsletters and articles on the Chinese revolution, Chinese worker movements and peasant movements in the Czechoslovak Communist Party Journal Creators. In 1935, he wrote about the Chinese Red Army's advance, and after the founding of new China, he introduced and praised new China with even greater passion. In 1949, he published The Chinese people to fight for freedom, translated it into Slovakian himself. This book has now been translated into Polish and Hungarian. ${ }^{2}$

Prusek graduated from Charles University in Prague in 1928. He was the first democratic Czechoslovakian Republican at Prusek's youth school stage. His stay in China from 1932 to 1937 was the so-called ten golden years construction time for the Chinese National Government. However, the political ideology of Prusek was less mentioned compared to his sinological research, but according to his actual doings, including the persons he met in China, and his political articles, he appeared to have to a certain degree an affinity with socialist China and Czechoslovakia's Communist regime of the 1950s and even the 1960s. Seemingly due to Prusek's political attitude or political ideology, he got support from the Czechoslovakian and Chinese Communist regimes which in the end led to the founding of the Prague School of Sociology.

Prusek had been to China more than three times in addition to his academic visits from 1932 to 1937 . The second time he went to China he acted as the delegation head of the Czechoslovakian culture representatives from December 10, 1950 to February 23, 1951. They went to Beijing, Shanghai, Hangzhou, Guangzhou, and Wuhan. This China visit lasted more than two months, in which they visited many political, academic and social people from all walks, and also visited factories, schools, libraries, museums, and nurseries. They enjoyed new Opera and Peking opera performances. Chinese newspapers reported Prusek's trips to China in detail, for example the People's Daily from 12.12.1950, 14.12,

1 Prusek Jaroslav, My Sister-China (Beijing: Foreign Language Teaching and Research Publisher, 2005). The quote is from the preface, page 2.

2 Yanning Li, People's Daily, October 41956. 
18.12 22.12, 3.1.1951, 16.2, 29.3.1951 all record in some length about Prusek's trip, this significantly demonstrates the Chinese Government's emphasis on Prusek delegation. During Prusek's second visit to China, they had another important job, which was buying books. The Czech Institute of Oriental Studies established "the Lu Hsun Library" in 1952 (Guo Mo-RUO's inscription), which became the largest Chinese language library in the Central Europe. The establishment of the Lu Hsun Library was related to Prusek's purchasing of many books in China, which he brought back to Prague in 1937 to the Oriental Institute. "However, a real Chinese library could not be established in Czechoslovakia in capitalist times. Only with the establishment of the Czechoslovakian workers and peasants Government, their sinological aspirations can be achieved. The Chinese Government provided them with an amount of Chinese books as gifts from the Chinese people. In order to meet the growing China interest of the Czech people, Czech sinologists put efforts and got full support from the Czech Government, and the Chinese library was finally born in Prague". ${ }^{3}$ People's daily (1952.11.3, and 1957.3.12) and Wen Wei Po (1959.3.29) had similar reports on the Czech Lu Hsun Library.

This paper, firstly, uses China's official newspapers to track Prusek's relationship with China, with the main purpose to guide the research understanding, that is, the 1950s socialist ideology, especially for Chinese Socialist identity, is essential to the external factors of founding the Prague school of Sinology. The author puts forward a possible research argument, that is, without 1950s Communist China, no 1960s Prague School of sinology. A Wen Wei Po article of March 29, 1959 "Czech sinology research to flourish, a large number of books and works to introduce China", in which there is a section written which states "Czechoslovakian Sinologists were under careful study of China's great leap forward. They often held various workshops on China's Socialist construction period and political and economic developments, and invited people who had ever visited China for reports on communes, the universal steel movement and the Cultural Revolution in China. They were particularly interested in a lot of poetry created by the working people in China during the Great Leap Forward, and some sinologists are ready to translate these poems." ${ }^{5}$ China's official newspapers are naturally full of ideological language. However, besides a political ideology to provide the Prague school of sinology with external support, how was it possible for the Czech sinologists not to involve the social ideology during the critical era of the 1950s? Especially one of the important connotations for the Prague School of sinology is the exploration of Chinese modern literature, despite volume of creation sharply shrinking for many left writers of the 1930s and 1940s into new

3 Nei, Lu Hsun Library of Prague, People's daily, March 121957.

4 Wen Wei Po, March 291959.

5 Ibid. 
China, but there should be its continuity for social concern through their early works of China writers. That should be a correlation between social ideology and concern on China's modernity.

In September 28, 1956, Prusek served as the head of the Czechoslovak Academy of Sciences delegation visiting China for more than one month (1956.9.28-11.8), and two Academies of Science (China and Czechoslovakia) signed a cooperation agreement for the period. This is the third time for Prusek to visit China ${ }^{6}$ Besides the factor of his health, the political environment of China and Czechoslovakia after 1960 was also gradually changing; factors were China-Russian hostility towards each other, the Chinese Cultural Revolution and the Czech Prague Spring movement. The young Czech sinologists, even though they had studied in China in the 1950s and had gotten their international reputation in Sinology in the 1960s, had few opportunities to go back to China until the 1980s. However, the 1950s studying experience of young Czech sinologist in China remains the most legendary compared to their western counterparts. The foundation of the Prague School of Sinology was mainly based on Prusek's personal contributions and external political factors, however the research question and research interest of this article is somewhere between sinology and socialist ideology.

\section{An Empirical Research and a Political Framework of Sinology}

The empirical data collected in this article consists of two parts, one is China's official data and media reports, and the other are interview transcripts from sinologists of the Prague school. These two kinds of material properties have obvious differences. On the one hand, China's official data from the 1950 s certainly have their own ideology and are written from the Chinese perspective. Sinologists from the socialist countries on the other hand strive for friendly relations between the Socialist International and China in the 1950s' under the Cold War structure, and China provided top academic resources for other socialist countries. Foreign students studying in China in the 1950s were from other socialist countries (for example, Table 1 and Table 2), this paper collects official data to show Chinese supports for foreign students coming from socialist countries to study in China in the 1950s. In addition, the other empirical data came from interviews with Czech sinologists, which is interesting because they have experienced the political purge of the Prague Spring and the end of the Communist regime in 1989. This paper adopts Halbwachs' theory regarding collective memory to analyze and explain the content of the interviews, and tests the research hypothesis of "socialism" as the social framework of the collective memory.

Under Prusek's influence on the Prague School of sinology, whose research

${ }_{6}$ People's Daily, 1956.9.29, 10.19, 10.22 
mainly focused on modern Chinese literature, many of these sinologists are very familiar with the famous contemporary Chinese writers, and often even take them as their main research objects. Sinologists of the Prague School studying and living in China in the 1950s are also my research interest in this study. The young sinologists studied in China, traveled, paid social visits, made friends and so on, and their interaction with and concern of Chinese society at that time no matter in works, ways of thinking are also the research goal for this paper. I think socialism in the 1950s, either in China or in Czechoslovakia is full of passion, but with the implementation of political purge movements, how did political ideologies react to their sinological studies is also an issue worth exploring. However, this does not mean that socialist concern must reach to the reduction of sinological achievements. Socialism is the political and social mainstream in the 1950s, however, the author has no clear position to define how clear or blurred the boundaries between Sinology and Socialism are.

This paper uses collected Chinese media, official records and interviews with the Sinologists from the Prague school of sinology to reconstruct their studying and living memory in 1950s China. It also discusses how they could acquire knowledge and emotional support in China in their early stages of sinological thought formation. The following materials are the records of foreign students number in institutions of higher learning in Beijing, China in 1959 (Table1) and 1964 (Table 2), both of which are collected by the author in Beijing. Since the end of the 1950s, Sino-Soviet hostility had been growing, the Soviet Union and the Eastern European countries gradually reduced the amount of students to China, and in the 1960s the number of students from the former Soviet Union and Eastern Europe to China became very small. We can see in Table 1 that in the late 1950 's the nationality of foreign students in China is still dominated by those from socialist countries. Vietnam was the leading sender of foreign students, followed by the Soviet Union. At this point the amount of students from Czechoslovakia is 9 , which is modest compared to other socialist countries. Referring to the year 1964 (Table 2), due to the serious situation of Sino-Soviet hostility, almost all Soviet students left China. Therefore, the 1950s can be seen as the key period for Soviet and Eastern European students to study in China, in the 1960s they gradually left because of political reasons.

Table 1 Foreign students in institutions of higher learning in Beijing, 
China in 3. 1959

\begin{tabular}{|l|l|l|l|l|l|}
\hline Country & N & Country & N & Country & N \\
\hline Soviet & 71 & Bulgaria & 4 & Italia & 2 \\
\hline Vietnam & 358 & \multicolumn{2}{|c|}{$\begin{array}{c}\text { 11 socialist countries, 601 } \\
\text { students }\end{array}$} & Nepal & 2 \\
\hline N. Korea & 45 & Indonesia & 36 & Australia & 2 \\
\hline E. Germany & 36 & United Arab & 14 & France & 2 \\
\hline Mongolia & 36 & Spain & 4 & Yugoslavia & 2 \\
\hline Poland & 14 & India & 3 & Ice Land & 1 \\
\hline Hungary & 12 & Thailand & 3 & Norway & 1 \\
\hline Romania & 12 & Sri Lanka & 2 & Denmark & 1 \\
\hline Czechoslovakia & 9 & USA & 2 & Iran & 1 \\
\hline Albania & 7 & Burma & 2 & 17 capitalist countries, 80 \\
& & & & \multicolumn{2}{c|}{ students } \\
\hline
\end{tabular}

Data Resource: Reference for higher School(7)' Archive Office in Beijing

Table 2 Foreign students in institutions of higher learning in Beijing,

China (1964.12)

\begin{tabular}{|l|l|l|l|l|l|}
\hline Country & N & Country & N & Country & N \\
\hline N. Korea & 58 & Cambodia & 4 & Chad & 1 \\
\hline N. Vietnam & 320 & Burma & 17 & Uganda & 1 \\
\hline Albania & 47 & Laos & 4 & Nigeria & 1 \\
\hline Cuba & 17 & Thailand & 6 & British & 1 \\
\hline Mongolia & 24 & Sri Lanka & 10 & France & 20 \\
\hline Poland & 2 & Afghanistan & 3 & Belgium & 1 \\
\hline E. Germany & 1 & Pakistan & 7 & Italy & 1 \\
\hline Romania & 5 & Japan & 7 & Sweden & 2 \\
\hline Bulgaria & 2 & S. Vietnam & 5 & Swiss & 2 \\
\hline \multicolumn{1}{|c|}{9 socialist countries, 476} & Syria & 1 & USA & 2 \\
\cline { 1 - 3 } Indonesia & 38 & Cameroon & 14 & 25 capitalist countries, 194 \\
\cline { 1 - 3 } Nepal students & 36 & Tanzania & 10 & \multicolumn{2}{|c}{ students } \\
\hline
\end{tabular}

Data Resource: Reference for higher School' Archive Office in Beijing

In addition to data validation through China's official reports of foreign students in 1950s to explore China's exchanges with other socialist countries, Table 3 is the content analysis of the Shanghai based Wen Wei Po newspaper which examines the coverage of overseas sinology on China. The author also collected data from the Xinmin evening newspaper, but the report sample is too small, so there is no adoption here. Newspapers discontinued in the 1970s because of the Cultural Revolution, however, the period of the 1950s can be seen in Wen Wei Po report for overseas sinology mainly focused on development of 
Soviet Sinology, otherwise reports from the 1950s and 1960s had few reports of Western sinology, however thereafter they increased until 1980. This can also be seen from the past trend of de-capitalization in China and the return of emphasis on the role of capital markets. There are market forces in the field of sinology as well.

Official data currently collected in this article is still fairly limited, and from this limited data can only be seen an initial development of sinology in the 1950s under China's political framework. As for Czech sinologists in the 1950s and their study and living conditions in China, the author will continue to collect official data/materials. There are a number of national policies and regulations relating the study and living situation for foreign students in China since the 1950s, like according to the regulation of "Several points for organizing foreign students out for traveling"(1963) in the universities, in which the 2nd point is "the school personnel leading students out to visit should hold introduction letters, indicating political face in order to arrange the reception, and the leading people should be responsible to tell the details about the students situation to the reception units ". In addition, an official notice, "About foreign students to buy recreational or sports tickets with care"(1964), in which the first point states "Beijing's major theatre, cinema, sports stadium tickets are available for foreign students. Schools for foreign students by the Principal Office or the international student Office of introduction letters to the theatre, cinema, sports, and it is ok to contact the ticket office". Some of the links may be of considerable importance for foreign students studying and living in China, such as the "introduction letter" and students' "political face" and so on, these experiences of studying abroad may affect students' knowledge of contemporary Chinese society, so that this paper will be back to explore 1950's Czech sinologist experience of studying in China.

Table 3 Reports of Sinology from Wen Wei Po

\begin{tabular}{|l|l|l|l|l|l|l|l|}
\hline & Soviet & Czech R. & France & USA & Japan & Germany & Swiss \\
\hline $1950 \mathrm{~s}$ & 9 & 1 & 0 & 0 & 0 & 0 & 0 \\
\hline $1960 \mathrm{~s}$ & 1 & 0 & 0 & 0 & 0 & 0 & 0 \\
\hline $1970 \mathrm{~s}$ & 0 & 0 & 0 & 0 & 0 & 0 & 0 \\
\hline $1980 \mathrm{~s}$ & 2 & 0 & 2 & 1 & 1 & 1 & 0 \\
\hline $1990 \mathrm{~s}$ & 5 & 0 & 0 & 1 & 0 & 0 & 1 \\
\hline
\end{tabular}

\section{Theory of Collective Memory}

This paper uses the theory of "collective memory" from Maurice Halbwachs (Halbwachs 2002) for the analysis of structure. The first person researching "collective memory" was the French scholar Maurice Halbwachs (1877-1945), who believed that the discussion of memory must be distinguishable from 
traditional psychology; in his view, psychologists limit memory to a personal level, but memory, just as people, can belong to many different groups, and thus people's memories will change due to these different groups. Halbwachs first used the nature of dreams to justify his "social framework". He pointed out that we tend to dream in fragmented pieces, which have a lack of structure, continuity, as well as rules, and are not rooted in social context and social structure. Dreamers would not be able to reminisce about their past in a coherent way, and these fragmented images could no longer support the specific groups to carry out their real lives and memories, making them unable to make real-life memory coherent and structured. ${ }^{7}$ Halbwachs compares real life with the dream world to prove that memory is conditioned by society. Each memory has its own social connections and social context, and memory must be triggered through society.

According to Halbwachs the carrier of memory can be an individual, a society, or a group, but the system itself cannot be recalled into memory, for that we need to understand the collective memory. Individuals are linked to multiple groups to which they belong, the strength of these links must be analyzed in order to be able to make sense of the relative strength of these memories, as well as their united way in individual thought. In short, to understand the collective memory one must analyze the group context an individual belongs to, because each memory requires a real body to keep it. Through Halbwachs' analysis of family memories, we can understand kinship as the social framework of family memories. Family memories receive meaning through this social framework and are introspective. Memory can continue through the social framework, while the social framework also changes with the social situation. This illustrates the modernity and instability of social framework. It is not just the carefree memories of the past for the people, but brings to surface memories of the past under the existing framework, especially for those who did not visit the past. As for the narrative of the framework, Halbwachs in his book mentions that only through positioning the memory in the corresponding group we can understand each section of memory in individual thought. Moreover, unless we correlate the individual memory to the multiple group memories that he or she belongs to, we will be able to properly understand the relative strength of these memories, as well as their united way in individual thought. ${ }^{8}$

Halbwachs divides memories into two types; historical memory and personal experience of the life course. The social framework will change because of the social situation, which also shows that the formation of collective memory is easily affected by the discourse of a power text, even by a purposive construction.

7 Lewis Coser, "Maurice Halbwachs on Collective Memory," American Journal of Sociology 91(1993).

8 Maurice Halbwachs, On Collective Memory(Shanghai:: People Publisher, 2002)., p. $93-$ 94. 
A man with power can control the collective memory of intangible abstraction through the holding of cultural media, as well as the control of relative material objects. Halbwachs, in his book The Legendary Topography of the Gospels in the Holy Land, studies from the same era the different memories of pilgrims to the Holy Land, and verifies that the memory is often fictional and discontinuous in nature. Halbwachs proves that "in every period in order to meet the urgent needs of Christianity and to adapt to their needs and aspirations, the collective memory of the Christian reformed all of its details on the life of Christ, as well as the memories of the locations for the appearance of these details." This illustrates that the truth of Christianity has been invented, and that churches rewrite the fictional Holy land into their Gospels in order to make these fictional facts seemingly more authentic. Therefore, in the collective memory, historical details are no longer necessary and present day beliefs and common experiences are sufficient conditions for constructing a collective memory.

In addition, Halbwachs in the chapter "collective memory of religion" explains that religious memory is not saved in the past, but that it reconstructs the past by virtue of material relics, rituals, scripture, tradition, and even recent materials from psychological and social fields; in other words, it is the "now" the past is reconstructed in. " (Halbwachs 2002:200) In other words, the collective memory is vulnerable under the current concern. In addition, religious memory tries to link the past and present together through repeated rituals and traditions of the past, and because it is often anchored in a historical context this strengthens the legitimacy of the religion itself. Similarly, the forgetting of memory is also the outcome of power relations. When a stronger memory appears, the original memory might be replaced or even excluded.

To sum up, collective memory has three characteristics: first, collective memory must be able to continue when anchoring in a social framework; second, the social framework is constructed by the present, in the current moment; third, collective memory has a fictional and utilitarian nature. As for the characteristics of collective memory, the author argues that the present social framework for the experience of Czech sinologists studying and living in China in the 1950s is constructed between sinology and socialism, thus, one should look to sinology and socialism in order to reconstruct the collective memory of Czech China experiences in the 1950s. The social framework of the 1950s' collective memory is referred to as specifically different from the following two periods; the 19701980s' encompassing Czech normalization, the Chinese-Russian relation split, and the Chinese Cultural Revolution and the Czech democratization of the 1990s. The development of Czech sinology is obviously affected by politics and has especially received serious influence from the Prague Spring. The collective memory of 1950s Czech Sinology is gradually invested into a legend of Czech

9 Ibid., p. 407. 
Sinology. This paper first reviews China's official records and papers of empirical data from the 1950 s to analyze the studying circumstances of students from international socialist countries in China, and secondly, China's official reports on international sinology to see how the Chinese government put emphasis on sinologist developments in socialist countries. In addition, this paper also makes use of nine in-depth interview transcripts, provided by Professor Olga Lomova and her colleagues.

\section{Analysis on Collective Memory}

Most Czech sinologists were inspired into sinology by Prusek and the founding of new China. Prusek's book My Sister China is full of his Chinese adventures in the 1930s, which became an important reading for Czech readers to get to know contemporary China. Milena Velingerova for example is a sinologist who started her career of sinology after reading Prusek's book. She said "I came to the faculty in 1950 after many difficulties caused by my family background. My motivation had nothing to do with the political situation in China, as we can hear all the time, but I received professor Prusek's book as a birthday present when I was eighteen. I did not know professor Prusek at all and I wasn't interested in him, but as soon as I read the book I knew this was the right thing for me to do." Venceslava Hrdlickova also mentioned the importance of Prusek's book and new China: "For my husband it was history providing him some larger view over the world events. We were going out together, exchanging books, discussing, he was mentioning China frequently. I think Prusek's My Sister China was published and the translation Vsichni lide jsou bratri...So we were taken, or he was taken by China, he expected it was a country with a great future."

In addition to the inspiration provided by Prusek's works and Prusek himself, the establishment of new China also attracted Czech young people's interest in Sinology. Zdenka Hermanova talked about his first encounter with sinology: "I didn't want to study English, I wanted something special. The PRC was established in 1949. I was taken by that and I went to the university. I wanted to study Chinese and Japanese, but Japanese wasn't open that year. We got Far East History as a second subject. I wasn't satisfied with it, so I went to Prague to protest. This was the first occasion I talked to professor Prusek." Josef Kolmas is another person who noticed new China: "Of course! He told me I had to go to Prusek first with my request...Thanks to the circumstances I started to study Chinese- and the history of the establishment of the PRC, Chinese delegations, the textbook of Bartusek and Palat and of course the transaction between Olomouc and Prague..." Venceslava Hrdlickova gave her husband as an example of being under the influence of Prusek and new China: "No, I think not, he was interested 
in sociology at the time we started to go to Prüšek, that means before we went to university. He was interested in China's future, and thereby in the possibility of learning about such distant societies."

In short, the combination of the two factors, Prusek and new China, created a new development of Czech Sinology. If it would have lacked either of the two factors, the development of Czech sinologist afterwards would probably not have been as brilliant. Therefore, Zbygniew Slupski said:

I would call them the China-specialists. So I am not the founder, Prusek was a founder. Prusek indeed was a exceptional person. He was like this even before, in the thirties, when he travelled to China. He had distinctive opinions at that time. Here he belonged to the left intelligence, and as he went to China, his worldview was all done. Read My Sister China, the man speaking there is a man who knows what he wants, where he is heading and what the future would bring to him. After the Second World War, and especially after The February Revolution Prusek understood, that the chance came to establish the sinology here, and he used the occasion- he took up with the growing political party. Thanks to this he could establish sinology here."

China and East European countries had few interchanges or correlations in the past, however, the international system during the Cold War narrowed down the distance between China and Eastern European countries. During the Nazi occupation of Czech from 1939-1945 universities were forced to close, but Prusek still actively promoted sinology in Czechoslovakia until the end of World War II. When new China was founded, the Czech Government urgently needed Chinese experts, therefore, China studies occupied quite an important position in Czechoslovakia in the 1950s. Augustin Palat described the situation as follows: "When Průšek tried to enforce something for the existence of the discipline in 1947 or 1948, he got always the same stereotypical answer: we are in the middle of building a two-year plan, we have no time now. After the PRC was established, this changed overnight. The authorities wanted crowds of people who would be able to speak Chinese, in the shortest possible time." Even Czech companies considered China a huge market and sent their employees to learn Chinese. Vladislav Drinek was such a case: "I was a worker in the Bata company, you know, the young man by Bata. There I first heard about the Chinese prospective market and about the necessity to focus on it. Generally, I was interested in history. That was all, my interest didn't go too deep. As a trainee of Bata high industrial school I got a basic education about China."

The mutual interaction with Prusek and new China plays a vital role in the construction of the collective memory of Czech sinologists in the 1950s. Prusek's heritage, including his writing works and those Chinese contemporary literature writers he met in China in the 1930s, offered the younger generation of Czech 
sinologists cultural capital, for instance it inspired Zbygniew Slupski to research Lao She, Marian Galik Mao Dun and Milena Velingerova Guo Moruo. Prusek's writings on Chinese contemporary literature happened to be in line with the mainstream thoughts of China's socialist transformation, and Prusek's political, academic and cultural resources so became the main factor of developing Czech sinology with its own special features. Milena Velingerova indicated the Czech features as following:

We knew nothing about classical Chinese literature. Professor Průšek said: I know the modern Chinese writers, we'll talk about them, our discipline shall deal with modern Chinese literature. From today's point of view, there is something special about Czech sinology: things were done not after the Chinese model, not after the western model - the western world followed Chinese, there was no one to do modern Chinese literature - since professor Průšek had his own reasons for it, I mean he didn't know classical Chinese literature, you know. But he knew people, the writers, and he had a great significance for us, because he knew those people and he has seen China. So Czech sinology was a pioneer in a totally different approach to sinology, I think this made a strong impression on us, at least on me.

Oldrich Svarny suggested "Průšek founded Czech sinology and his aim was to cover every field of China studies of course. I was chosen as a Chinese phonetician." Venceslava Hrdlickova stated that even though Prusek emphasized contemporary Chinese studies, but he never neglected the importance of history. She said: "We were astonished, charmed when he (Prusek) had a talk with us about the plans for future, his foresight and instinct became evident as early as here: he was interested in modern China, in the China that was to be, and not... Well of course, he stressed the importance of studying history, but not only history, he expected us to think ahead. So this was our very important meeting." Zbygniew Slupski judged Prusek from another perspective:

He definitely was an extraordinary person. It is hard to judge the quality of his founding act, since there was nothing to start from: there were no books, no other materials, no money, no nothing. So Průšek started from scratch. Thanks to the fact Průšek was a significant political figure in the academic world, he enforced many things - the library, money for the employees - so sinology could begin somehow. What was the teaching standard? Well, of course it wasn't that good from a current point of view, but how could it maintain some standards when there were no basic reference books?"

Marian Galik and Joself Kolmas also offered different judgments toward Prusek. Marian Galik: "I remember one thing which is quite typical for Prǔšek. I told him I would work on Mao Dun's short stories. He reacted in front of my classmates: the modern Chinese short story is worth nothing except for Lu Xun's 
short stories. After two years he worked on it - on the basis of my paper....That was Průšek." In addition, Joself Kolmas: "Průšek was... a streamlining person. He had the idea, but he wasn't able to elaborate it. This he left to the others - and they appreciated it: thank God someone had an idea! Those who caught the idea were grateful for getting the impetus until their death. He had the insight, it was his greatest virtue. Gálik says Průšek had many many ideas, but he didn't make a proper job of them. This is Gálik's theory. Gálik needed to finalize the idea.

Most of the interviewees, except for Vladislav Drinek, once studied under Prusek, and were affected by Prusek as well, and during their stay in China for learning sinology they also copied Prusek's experiences from the 1930s more or less. As for the development of Czech sinology, Prusek was a legendary figure. Due to Prusek's personal influence, the development of Czech sinology is primarily bent towards Chinese contemporary literature. Zbygniew Slupski believes that this development was based on the Czech cultural tradition, and makes a comparison with Polish sinology: 'It seems to me that Czech sinology's development follows the Czech cultural tradition: poetry and arts firstly, history and philosophy in a lesser degree. In Poland, for instance, very few are interested in Chinese literature or Chinese art. There is the only man able to do it on the academic level. But there are people who devote themselves to the problems of politics, ideology, and economy. There is a great concern about political developments and political institutions." Prusek can be taken as a collective memory of Czech sinologists, and in spite of different evaluations toward Prusek, it couldn't change how important he was to Czech sinology.

Another collective memory of the $1950 \mathrm{~s}$ ' Czech sinologists is their experience in China, including school learning, work and travelling. Milena Velingerova's first impression of the Chinese Communist Party seemed strange: "The Chinese communist party is a democratic party, so it had to use democratic ways to get to power. I said something about the farmers and their better living under the communist party, as I read in the book, and that was all. I got no answer." Vladislav Drinek's first knowledge about China: "It was all something new. Five thousand years of history and what China represented in the world history. The backward situation of contemporary China was somehow weird in this light. Marian Galik took China as a strange country:"I read various things in the books: Chinese are stingy and arrogant, they offer something and they expect you to refuse it. So my image of China wasn't very nice at all."

Different from sinologists from non-socialist countries, the young sinologists of Eastern Europe could go to China to study and actually be in touch with socialist China's social development. Czech young sinologists could study for a diploma in China possibly for up to four years or more. Zdenka Hermanova had a long stay in China for an academic diploma: "I was proposed the scholarship to China in 
$1953 \ldots$ I attended the language course one year together with Korean students,... After that year we entered Zhongwen xi,...Me and Vochala wanted to have our diploma recognized, so we got one more semester to write the degree work. And thus we came back in 1958 in spring." However, Milena Velingerovastayed was in China just for one year: " By pure accident I came to China - professor Průšek picked me up as the guide for ZZD (Zhen Zhenduo) for unknown reason. So I came to China and immediately I got into the elite nest of outstanding people in the institute for Chinese language and literature." "I was in China in 19581959, during the most terrible year of The Great Leap Forward." I travelled across China and I found out about it only after I came back. I travelled with two students from Poland. With one document I made a tour around all of China."

Venceslava Hrdlickova accompanied her husband, who worked as a cultural attachй during 1951 and 1954; however, they had already visited China in the delegation led by Prusek in 1950. She said "I wasn't a delegation member, I traveled as the wife, my husband was expected to stay as a cultural attachй, so I traveled as a family member, but I was not an official member of the delegation... And our delegation traveled across China. Of course we were watched, we couldn't go wherever we wanted, but we went to Nanking, Kanton, to Lu Xun's hometown. The friendship between Prǔšek and Lu Xun played a significant role in it, because he was honored by the government of the time." However, when they worked in China, they did not travel too much. "Well, we could not travel so much at that time." Augustin Palat worked as a cultural attachй after the term of Hrdlickova's husband from 1954 and 1959. Palat appeared to keep good social relations and traveled a lot, he even made friends with the Dalai Lama in Tibet.

Marian Galik got Pruseks help and went to China in 1958, and stayed there for more than one year. He said: "Professor Průšek gave me jieshaoxin addressed to Mao Dun... When I pulled my jieshaoxin out of my pocket at the liuxuesheng bangongshi, they connected with the ministry of culture and one month later I met Mao Dun...I went to Wu Zheng and I was the first foreign sinologist to go there... I used to go to the library, I travelled, and I was buying two sorts of books: those about Mao Dun and those about Yu Dafu. Mrs Doležalovб could never have written her book without me. How I did it? It was simple. I learned that guanxi were important. When Mao Dun told me I should meet Mister Yue Yiqin there at one jump, who was then a chairman of the Shanghai Chinese Writers Union. This man gave me a jieshaoxin to the largest Jiao Shudian Menshubu."

Czech young Sinologists had the opportunity to go to China for study, work and traveling in 1950s, but the important thing was that they still maintained a close relationship with Prusek. Galik took the introduction letter from Prusek to visit Mao Dun. Velingerova was once introduced to Zheng Zhen-Duo during his stay in Czechoslovakia, ZZD then provided her with warm assistance in China, 
and when Hrdlickova and her husband joined the Czech cultural delegation in China, Prusek introduced them to get to know many people from cultural circles in China. Palat also maintained a close working relationship with Prusek. The experiences of younger Czech sinologists in China are almost a reproduction of Prusek's in the 1930s, through the personal experience of social visits and getting acquainted with cultural figures in order to learn contemporary Chinese literature. Therefore, Czech sinology in the 1950s, to a degree, can be taken as an extended consideration of Prusek on China. In Communist China of the 1950s, young Czech sinologists were not entirely free to travel, but this could not prevent them from experiencing contemporary Chinese society. Real life experiences in China were very valuable, and while Westerners from non-socialist countries could not enter China, the works of Czech sinologists and exchanges in international symposia became first-hand information for Westerners to understand contemporary China.

Olga Lomova took her own learning experience in the 1980s and raised the following question to Slupski: "Now I ask my last question. What were the political demands on the students at your time? As far as humanities were concerned, the university students of my generation were hardly examined during their studies. Politically reliable persons enjoyed priority when it came to the selection. This is what Kubešová herself told me: don't think you are clever, we always prefer loyal people... Did political pressure affect the personal forming of sinology at your time?" Slupski replied: "Well, the pressure existed, there was a basic cell of the communist party that guarded those things."

The collective memory of Czech Sinologists in the 1950s is mainly related to Prusek and new China; however, the social framework of the collective memory in 1950s Czech sinology is mainly in a mixing zone between sinological development and the effects of political ideology. Therefore, despite the fact that most of the interviewees did not deliberately talk about the political ideology in the 1950s, political influence still always existed.

\section{Conclusion}

The China experience of the 1930s for Prusek had a long effect not only on his own sinological achievements, but also on later generations through his works and the founding of the Prague School of Sinology. Nazi Germany occupied the Czech Republic in 1939, which forced Czech universities to close. After World War II had ended, Prusek taught in Charles University. The Czechoslovak communist regime was established in 1948, while the Chinese communist party took over China in 1949. Prusek began selecting Czechoslovak students to be sent to China for studies in the early 1950s, which retained for a period of about ten years, and then stopped sending the students due to Sino-Soviet hostility in the 1960s, the 
Chinese Cultural Revolution and the Prague Spring. Prusek, in addition to his individual academic abilities, made significant contributions to the development of sinology in the Czech Republic, the promotion of China and Czech-China cultural and academic exchanges. Prusek had a good relationship with affinity for socialism in China at that time. Prusek studied in the Chinese society of the 1930s, and got to know China's left-wing writers, making his China links closer to socialist China, instead of the ruling Kuomintang government. After 1949 Prusek once served as the delegation head to visit China for several times in the 1950s and due to his good relationship with the new Chinese government and Chinese society, he could promote cultural and academic exchanges between China and the Czech Republic. However, Prusek and other Czech sinologists refused to criticize China in the wake of the Prague Spring movement, therefore they were purged. Actually, sinology and 1950s' Chinese socialism are important factors in the life-history of all the sinologists who went to China at the time, because of their actual experience of studying in China, and their memories of China that had a strong connections with social life.

However, due to the Chinese Cultural Revolution, the Prague Spring movement and the collapse of the Czech Communist regime, Czech sinologists in the interviews talked few about the passion and ideals of socialism in 1950s' China. As for Halbwachs' theory of collective memory, the present social framework is the key point to reconstruct the past. The mainstream of today's ideology is no longer socialism, therefore, the social framework of their collective memory in the 1950s might also be "de-socialized", a theme that should be delved into deeper in future research. In my personal interviews with Czech sinologists, their devotion to sinology for life deeply moved and shocked me. Their writings almost are of an astronomical number, at least above 600 or 700 pieces of academic work. The fact that Czech sinologists in the 1960s could acquire a reputation in the international sinology field, should be associated with their 1950s' experience in China.

The construction of a collective memory in the 1950s for Czech sinologists is mainly based on the political zone between sinology and socialism. First of all, the relationship between China and Czechoslovakia was friendly, so they exchanged students. Secondly, Prusek was the leading force of Czech sinology and this led to the collective achievements of the Prague school. In the 1950s, however, there existed political censorship in China and Czechoslovakia. Even though this was unlike the more serious situation of political persecution in the 1970s and 1980s normalization movement, these were still negative factors interfering in the free development of Czech Sinology. Prusek was a legend of Czech sinology, that is to say, there would have been no Czech sinology in the 1960s without Prusek. In other words, Czech sinology in the 1960s was a good time that was mainly based 
on the accomplishments of a group of young Czech sinologists that had been led by Prusek in the 1950s.

\section{Bibiography}

Coser, Lewis (1993) Maurice Halbwachs on Collective Memory." American Journal of Sociology 91: 20-39.

Halbwachs, Maurice (2002) On Collective Memory. Shanghai:People Publisher.

Jaroslav, Prusek (2005) My Sister-China. Beijing: Foreign Language Teaching and Research Publisher.

Li, Yanning. People's Daily, October 41956.

People's Daily, 3. 3. 1957. 12.12.1950, 16.2, 29.3, 14.12, 18.12 22.12, 3.1.1951, 1951, 3.11.1952, 4.10.1956, 12.3.1957

Reference for higher School(7) (3.1959)' Archive Office in Beijing

Reference for higher School(12.1964)' Archive Office in Beijing

The regulation of "Several points for organizing foreign students out for traveling"(1963), Archive Office in Beijing

The regulation "About foreign students to buy recreational or sports tickets with care"(1964), Archive Office in Beijing

Wen Wei Po, March 291959. 